\title{
Critical Healthcare Assessment using WBAN and SVM
}

\author{
Tambe Sagar B, Patil Kunal A, Bhavare Pankaj C, Kendre Govind L
}

\begin{abstract}
Today good healthcare facilities and awareness of need of good healthcare is increasing in India. But as awareness increases it also strains the current healthcare infrastructure as patient expects more secured treatment round the clock. So there arises a need of remote assessment of patient health all the time using IoT devices. But these devices also need to be monitored by health worker in a hospital. Due to human interaction with theses IoT devices it may give rise to errors as human decisions can be late as a human health worker cannot look at the devices 24X7. So, to remove dependence of human decision-making technologies such as WBAN, cloud and machine learning has to be utilized together to make heath decision of a patient with less human interaction. So, we are designing a project where healthcare of a patient can be monitored extensively using WBAN. In first part of our project, we design a IoT device using Arduino and ESP8266 Wi-Fi module. The sensors connected to the Arduino will be pulse sensor, temperature sensor etc. The sensors will transfer data from patient to a server using ESP8266 and Wi-Fi called as WBAN network. The server will then apply SVM machine learning algorithm on the sensor readings and classify in two categories safe and unsafe. Custom made training dataset will be used to train the SVM. If unsafe readings are found the sensor will send a message to concerned doctor and upload readings to the cloud. The doctor on receiving alert can see the readings on the android app designed for the project and take a decision on the condition of the patient. For the project we are using Google Cloud Platform as our cloud provider which is free for use. Thus, by using our project a doctor can monitor his patient remotely from anywhere and the system will help in making decisions on the behalf of the doctor.
\end{abstract}

Keywords: Healthcare Assessment, IoT, WBAN, SVM, Mobile Computing, Cloud Computing.

\section{INTRODUCTION}

$T_{\text {he basic project idea is to remove the faults in the current }}$ healthcare facilities. Today's healthcare facilities are dependent on human decisions and communication to give proper healthcare to patient at the time of emergency.

Manuscript received on July 17, 2021.

Revised Manuscript received on July 23, 2021.

Manuscript published on July 30, 2021.

* Correspondence Author

Dr. Tambe Sagar B, Head of Department, Department of Computer Engineering, Pravara Rural Engineering College, loni (Maharashtra), India.

Patil Kunal A*, BE Student, Department of Computer Engineering, Pravara Rural Engineering College, loni (Maharashtra), India.

Bhavare Pankaj C, BE Student, Department of Computer Engineering, Pravara Rural Engineering College, loni (Maharashtra), India.

Kendre Govind L, BE Student, Department of Computer Engineering, Pravara Rural Engineering College, loni (Maharashtra), India.

(c) The Authors. Published by Blue Eyes Intelligence Engineering and Sciences Publication (BEIESP). This is an open access article under the CC BY-NC-ND license (http://creativecommons.org/licenses/by-nc-nd/4.0/)
The human interaction becomes cumbersome as it is prone to errors and cost a patient his life if decision making is poor or untimely. So, there is a lot of scope to remove the morbidities in the healthcare system and to make it effective with the same work force but by parting with the decision making to the computers who will take decision about the condition of a patient according to the readings from various devices. Thus, the idea is simple i.e., to provide better healthcare to the patient.

\section{CASE STUDY}

1. Hardware used for WBAN

\begin{tabular}{|c|l|l|l|}
\hline Sr.No. & Parameter & $\begin{array}{l}\text { Minimum } \\
\text { Requirement }\end{array}$ & Justification \\
\hline $\mathbf{1 .}$ & CPU & $\begin{array}{l}\text { Core i-3 and } \\
\text { Above }\end{array}$ & $\begin{array}{l}\text { For Multiple } \\
\text { Software's }\end{array}$ \\
\hline $\mathbf{2 .}$ & RAM & $\begin{array}{l}\text { 4GB and } \\
\text { above }\end{array}$ & $\begin{array}{l}\text { For Fast } \\
\text { Processing }\end{array}$ \\
\hline $\mathbf{3 .}$ & MODEM & $\begin{array}{l}\text { Good internet } \\
\text { modem }\end{array}$ & For internet \\
\hline $\mathbf{4 .}$ & $\begin{array}{l}\text { Arduino and } \\
\text { ESP Model }\end{array}$ & $\begin{array}{l}\text { Connected to } \\
\text { sensor }\end{array}$ & $\begin{array}{l}\text { For sensor } \\
\text { Reading }\end{array}$ \\
\hline $\mathbf{5 .}$ & Temperature & $\begin{array}{l}\text { Connected to } \\
\text { Arduino }\end{array}$ & $\begin{array}{l}\text { For Patient } \\
\text { body Reading }\end{array}$ \\
\hline
\end{tabular}

2. Software Used

Arduino IDE, Apache NetBeans, Weka, Android Studio, Android, Java Development ToolKit (JDK)

\section{EXPERIMENTAL PROCEDURE}

Major tasks in the project can be explained as: Task-1:- Get readings from IoT.

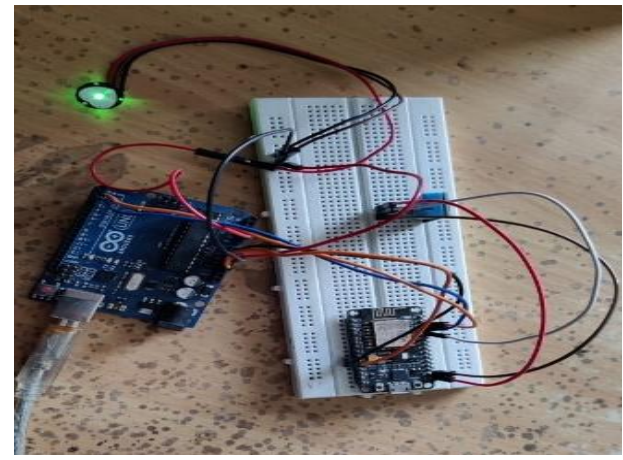

Fig 1. Connect Hardware

Arduino Module:-

This module is a IoT application. In this module readings are taken from pulse sensor using Arduino uno microcontroller. It will send the readings from pulse sensor to ESP8266.

Published By:

Blue Eyes Intelligence Engineering and Sciences Publication

(C) Copyright: All rights reserved.

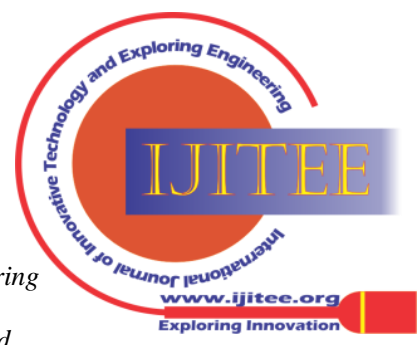




\section{ESP8266 Module:-}

In this module readings are taken from arduino uno and then it will take readings from dht11 temperature sensor and forward the readings to desktop server using Wi-Fi where the readings will be analyzed.

\section{Task-2:- Create training dataset.}

We create training data set of patient.

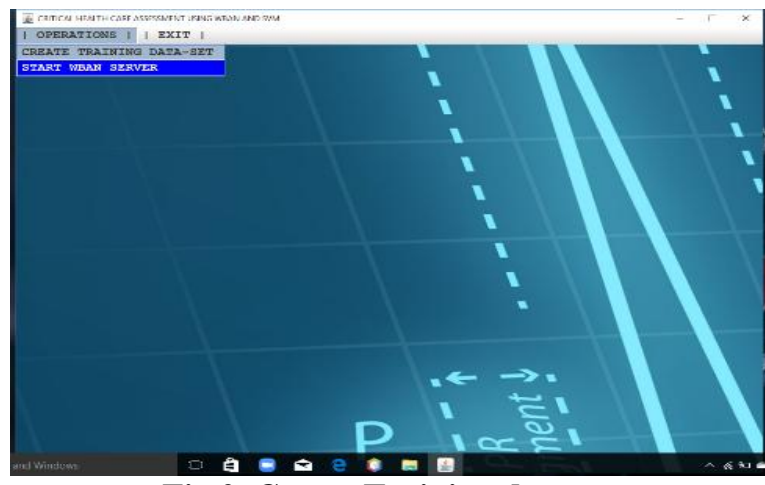

Fig 2. Create Training dataset

Task-3:- Create testing dataset.

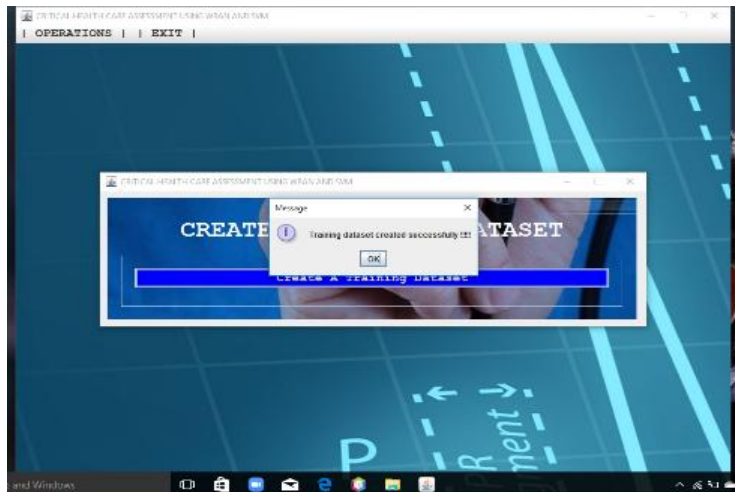

Fig 3. Create Testing Datasets

Task-4:- Apply SVM.

This algorithm will be used to classify input in to various classes as defined in training dataset.

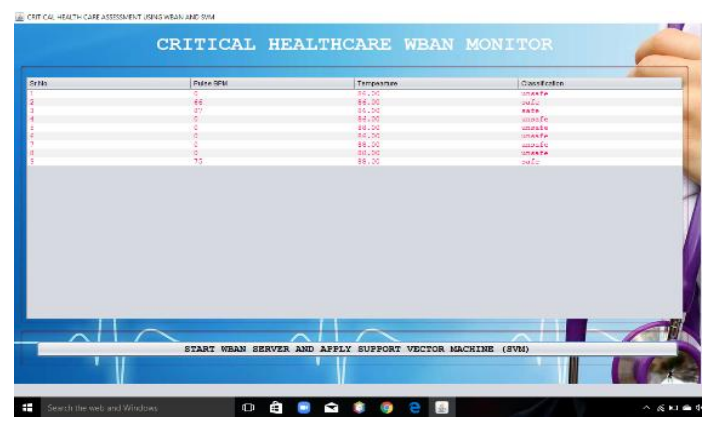

Fig 4. SVM Classification

Task-5:- Detect health issue.

We are using WBAN and SVM we are going to analyze the health of patient using two classes safe and unsafe. If unsafe readings are found the consent authority will alerted.

Task-6:- Send alert.

\section{Google Spreadsheet}

Google Sheets is a spreadsheet program included as part of a free, web-based software office suite offered by Google within its Google Drive service.

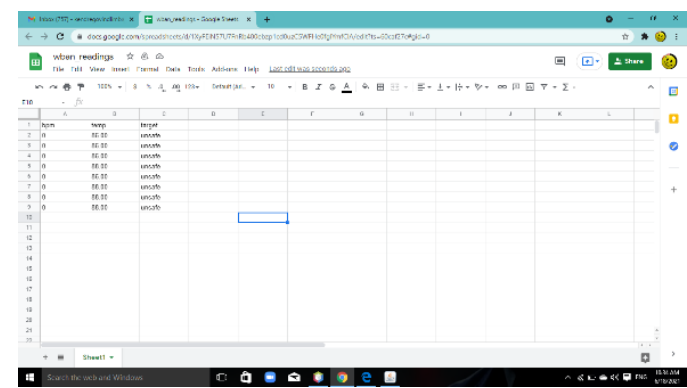

Fig 6. Google Spreadsheet

Task-7:- View alert.

This module is a mobile application. In this module a concerned authority can view the unsafe readings and take appropriate decisions.

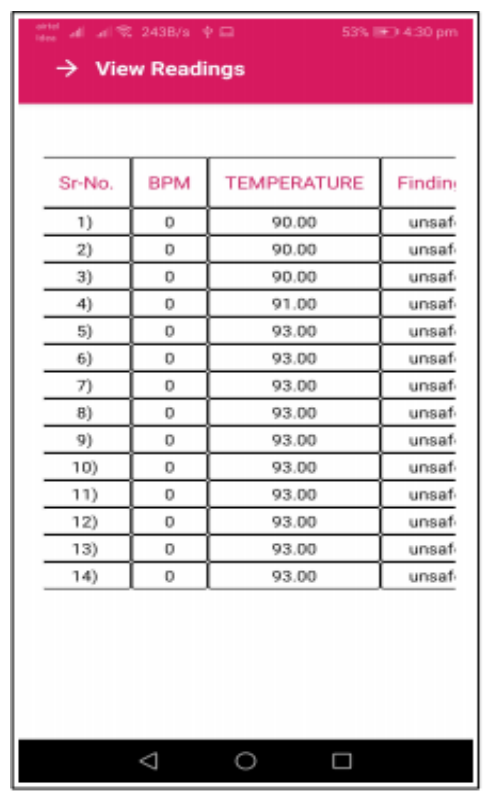

Fig 7. Mobile view Unsafe Reading

\section{TEST CASES}

1. Test cases for IoT module: -

\begin{tabular}{|c|c|c|c|}
\hline $\begin{array}{c}\text { Test } \\
\text { Id }\end{array}$ & Description & $\begin{array}{c}\text { Expected } \\
\text { result }\end{array}$ & Remark \\
\hline TI-01 & $\begin{array}{c}\text { Connect } \\
\text { sensor and get } \\
\text { reading }\end{array}$ & $\begin{array}{c}\text { Reading show } \\
\text { in arduino } \\
\text { IDE }\end{array}$ & Pass \\
\hline TI-02 & Send Readings & $\begin{array}{c}\text { Success } \\
\text { message }\end{array}$ & Pass \\
\hline
\end{tabular}

2. Test cases for mobile module: -

\begin{tabular}{|l|l|l|l|}
\hline Test Id & Description & $\begin{array}{l}\text { Expected } \\
\text { result }\end{array}$ & Remark \\
\hline TM-01 & View menu & Menu visible & Pass \\
\hline TM-02 & $\begin{array}{l}\text { View } \\
\text { Reading }\end{array}$ & $\begin{array}{l}\text { Reading } \\
\text { visible in } \\
\text { table view }\end{array}$ & Pass \\
\hline
\end{tabular}

Published By:

Blue Eyes Intelligence Engineering

and Sciences Publication

(C) Copyright: All rights reserved.

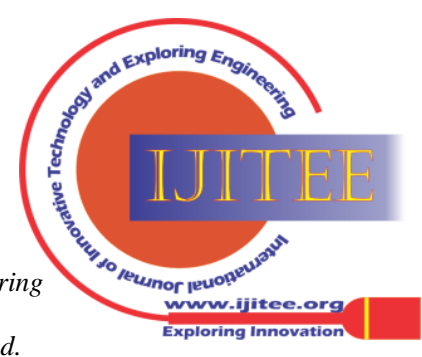




\section{Test cases for desktop module: -}

\begin{tabular}{|l|l|l|l|}
\hline $\begin{array}{l}\text { Test } \\
\text { Id }\end{array}$ & Description & $\begin{array}{l}\text { Expected } \\
\text { result }\end{array}$ & Remark \\
\hline TD-01 & $\begin{array}{l}\text { Authenticate } \\
\text { admin }\end{array}$ & $\begin{array}{l}\text { Menu } \\
\text { visible }\end{array}$ & Pass \\
\hline TD-02 & View reading & $\begin{array}{l}\text { Reading } \\
\text { visible in } \\
\text { table }\end{array}$ & Pass \\
\hline TD-03 & $\begin{array}{l}\text { Create training } \\
\text { dataset }\end{array}$ & $\begin{array}{l}\text { Success } \\
\text { message }\end{array}$ & Pass \\
\hline TD-04 & Apply SVM & $\begin{array}{l}\text { Success } \\
\text { message }\end{array}$ & Pass \\
\hline TD-05 & $\begin{array}{l}\text { Select unsafe } \\
\text { reading }\end{array}$ & $\begin{array}{l}\text { Send alert } \\
\text { message }\end{array}$ & Pass \\
\hline
\end{tabular}

\section{CONCLUSION}

In this project, we are developed novel collaboration of IoT, WBAN, machine learning, cloud computing and mobile computing together to create a more reliable healthcare assessment system. The basic idea of the project was to design a reliable decision-making system with remote handling of patient health with accuracy.

\section{ACKNOWLEDGMENT}

Thanks to the H.O.D. Dr. Tambe Sagar B.

\section{REFERENCES}

1. Safina Shokeen and Davinder Parkash.," A Systematic Review of Wireless Body Area Network.” IEEE-2019.

2. T. Ninikrishna, Mohit kumar, Nishit kumar, Parul karn and Rachana. S. V., "An Efficient IoT Based Body Parameters Telemonitoring System." IEEE-2020.

3. Honey Pandey and S. Prabha., "Smart Health Monitoring System using IOT and Machine Learning Techniques." IEEE-2020.

4. M. S. Mohammed, S. Sendra, J. Lloret, and I. Bosch, "Systems and WBANs for controlling obesity,” J. Healthc. Eng., vol. 2018, 2018

5. Hu, X. Liu, M. Shao, D. Sui, and L. Wang, "Wireless Energy and Information Transfer in WBAN: An Overview," IEEE Netw., vol. 31, no. 3, pp. 90-96, 2017.

6. M. Salayma, A. Al-Dubai, I. Romdhani, and Y. Nasser, "Wireless Body Area Network (WBAN): A Survey on Reliability, Fault Tolerance, and Technologies Coexistence," ACM Comput. Surv., vol. 50, no. 1, pp. 1-38, 2017.

7. A. B. and V. T. E. Monto' n, J.F. Hernandez, J.M. Blasco, T. Herve', J. Micallef, I. Grech, "Body area network for wireless patient monitoring," Eng. Technol., vol. 1, no. 1, pp. 122-130, 2007.

8. D. Wu, B. Yang, H. Wang, D. Wu, and R. Wang, "An EnergyEfficient Data Forwarding Strategy for Heterogeneous WBANs," IEEE Access, vol. 4, no. c, pp. 7251-7261, 2016.

9. Y. Kim, S. S. Lee, and S. K. Lee, "Coexistence of ZigBee-based WBAN and WiFi for health telemonitoring systems," IEEE J. Biomed. Heal. Informatics, vol. 20, no. 1, pp. 222-230, 2016

10. S. T. Ben Hamida, E. Ben Hamida, and B. Ahmed, A new mHealth communication framework for use in wearable WBANs and mobile technologies, vol. 15, no. 2. 2015.

\section{AUTHORS PROFILE}

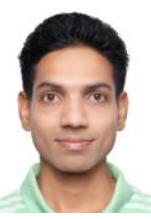

Mr. Sagar B. Tambe, is working as an Assistant Professor in the Department of Computer Science Engineering at Pravara Rural Enginerring college, Loni, Maharashtra, India. He is completed Ph.D from S.G.G.S. Institute of Engineering and Technology, Nanded, Also postdoctoral from University of Parma, Italy. He received his B.E. and M.E. degree in Computer Engineering from Pune University, Pune in 2010 and 2013, respectively. He published many papers in reputed conferences and journals. His research interests include Signal Processing, Bio-medical sensor network, Wireless Communication, etc.

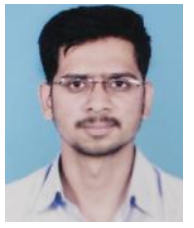

Mr. Kunal A. Patil, is currently pursuing B.E final semester in Computer Engineering at Pravara Rural Enginerring college, Loni, Maharashtra, India.

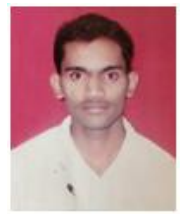

Mr. Govind L. Kendre, is currently pursuing B.E final semester in Computer Engineering at Pravara Rural Enginerring college, Loni, Maharashtra, India.

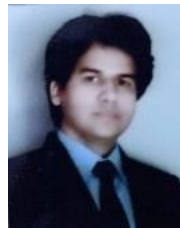

Mr. Pankaj C. Bhavare, is currently pursuing B.E final semester in Computer Engineering at Pravara Rural Enginerring college, Loni, Maharashtra, India. 